\title{
Antiprostaglandin synthetase activity of nonsteroidal anti-inflammatory drugs and gastrointestinal micro- bleeding: a comparison of flurbiprofen with benoxaprofen
}

\author{
A. C. YEUNG LAIWAH, ${ }^{1}$ T. E. HILDITCH, ${ }^{2}$ P. W. HORTON, ${ }^{2}$ \\ AND J. A. HUNTER ${ }^{3}$ \\ From the ${ }^{1}$ University Department of Medicine, Western Infirmary, Glasgow, the ${ }^{2}$ Department of Clinical \\ Physics and Bio-Engineering, West of Scotland Health Boards, and the ${ }^{3}$ University Department of Medicine, \\ Centre for Rheumatic Diseases, Glasgow
}

SUMmARY By using ${ }^{51} \mathrm{Cr}$-labelled erythrocytes and ${ }^{141} \mathrm{Ce}$-labelled microspheres to correct for daily variations in faecal output, gastrointestinal microbleeding was measured in hospital patients with rheumatoid arthritis before and after administration of 2 propionic acid derivatives. These were flurbiprofen and benoxaprofen, respectively a potent and a weak prostaglandin synthetase inhibitor. Increased faecal blood loss occurred consistently with flurbiprofen and not with benoxaprofen. Our results provide indirect evidence for the cytoprotective effect of prostaglandins on the gastrointestinal mucosa in man. The quantitative correlation between faecal occult blood loss as measured by the above techniques and the Haemoccult slide test is also discussed.

In recent years many nonsteroidal anti-inflammatory drugs (NSAID) have appeared on the market with the claim that they produce fewer gastrointestinal side effects, the most important of which is gastric bleeding. ${ }^{1-3}$ The majority of these drugs have been shown to have an inhibitory effect on prostaglandin (PG) synthesis as assessed by in-vitro tests; the suggestion has even been made that their clinical effectiveness as anti-inflammatory agents parallels their antiprostaglandin activity. ${ }^{45}$ Experiments using several animal models have firmly established that a large number of prostaglandin compounds exert a cytoprotective effect on the mucosa of the gastrointestinal (GI) tract. ${ }^{6}$ 7 If prostaglandins were to have a similar cytoprotective effect in man, it might be argued that no antiprostaglandin analgesic would be completely free from producing gastric damage.

The discovery of benoxaprofen, a weak PG synthetase inhibitor, ${ }^{8}$ allowed us to compare its gastrointestinal effect with flurbiprofen, reputedly a potent prostaglandin synthetase inhibitor. ${ }^{9}$ Both

Accepted for publication 22 October 1980

Correspondence to $\mathrm{Dr}$ A. C. Yeung Laiwah, University Department of Medicine, Gardiner Institute, Western Infirmary, Glasgow G11 6NT. drugs are propionic acid derivatives. In this study we measured the amount of gastrointestinal microbleeding before and after administration of these two NSAID at therapeutic doses in patients suffering from rheumatoid arthritis.

\section{Patients and methods}

Six patients suffering from classical rheumatoid arthritis ${ }^{10}$ were entered into the study. None of them had any known cardiac, hepatic, or renal diseases. Particular care was taken to exclude patients with a previous history of prolonged dyspepsia, peptic ulcer, and gastrointestinal bleeding. Proctoscopy was carried out to exclude any local source of anorectal bleeding. The patients were selected for inpatient treatment with bed rest and physiotherapy; many of these patients had unsatisfactory social circumstances. The purpose of the study was fully explained to each patient, whose consent was obtained only after 3 days' stay in the research unit to assess the situation. The option to withdraw from the study at any time was given to the patient at the onset of the study period. The clinical details of the patients are given in Table 1.

A seventh patient with rheumatoid arthritis with a 
Table 1 Clinical details of patients with rheumatoid arthritis

\begin{tabular}{lllllll}
\hline Case no. & Sex & $\begin{array}{l}\text { Age } \\
\text { (years) }\end{array}$ & $\begin{array}{l}\text { Weight } \\
(\mathrm{kg})\end{array}$ & $\begin{array}{l}\text { Duration of } \\
\text { disease (years) }\end{array}$ & Other diseases & Drug treatment on admission \\
\hline 1 & M & 72 & 60 & 20 & Migraine & * NSAID. dihydrocodeine \\
2 & F & 74 & 68 & 30 & Varicose veins & NSAID, diazepam \\
3 & F & 70 & 57 & 7 & Nil & NSAID, diazepam \\
4 & F & 59 & 43 & 8 & Nil & NSAID, penicillamine \\
5 & F & 57 & 63 & 5 & 51 & Nil paracetamol, temazepam \\
6 & M & 60 & 61 & 5 & Chronic duodenal and & NSAID cimetidine \\
$7 * *$ & F & 65 & 62 & 6 & gastric ulcers & \\
\end{tabular}

*NSAID = nonsteroidal anti-inflammatory drugs. $\quad$ "*Case 7 not included in statistical analysis of results.

documented past history of duodenal and gastric ulcers was studied separately. Before admission she had been treated with numerous NSAID 'under cover' of cimetidine. Endoscopy carried out before the study period revealed no active lesions but evidence of healed gastric and duodenal ulcers. She was then maintained on cimetidine, $200 \mathrm{mg}$ t.d.s. and $400 \mathrm{mg}$ nocte throughout the study period.

Tests were performed to identify those factors that might contribute to an increased bleeding tendency, namely, platelet count, clotting profile, and leucocyte ascorbic acid level. Table 2 gives the results of investigations performed on admission. The 3 patients with subnormal leucocyte ascorbic acid levels were given vitamin $\mathrm{C}$ supplements throughout the study period.

Faecal blood loss was measured by a standard technique after an intravenous injection of ${ }^{51} \mathrm{Cr}$ labelled autologous erythrocytes $(50 \mu \mathrm{Ci})$ at the onset of the study period. ${ }^{11}$ To correct the blood loss in each faecal collection for variations in daily faecal output the patient received a daily dose of $0.2 \mu \mathrm{Ci}$ cerium-labelled $\left({ }^{141} \mathrm{Ce}\right)$, inert, nonabsorbable microspheres ( $3 \mathrm{M}$ Company). The ${ }^{141} \mathrm{Ce}$-activity was measured simultaneously with ${ }^{51} \mathrm{Cr}$-activity in each stool specimen and used to correct the blood loss to a 24-hour basis. ${ }^{12}$ The radiation dose from the ${ }^{51} \mathrm{Cr}$ and ${ }^{141} \mathrm{Ce}$ was considered acceptable and approved by the Administration of Radioactive Substances Advisory Committee.

Every stool specimen passed was tested within 1 hour for faecal occult blood (FOB) by the Haemoccult (R) spot test. The aim was to compare the sensitivity of this method with the ${ }^{51} \mathrm{Cr}$-haemoglobin stool content.

Design of study. This was an inpatient study over a 6-week period starting with 1 week's run-in prior to which all NSAID were stopped. This was followed by a treatment period of 2 weeks when the patient was given either flurbiprofen or benoxaprofen in an open, randomised, cross-over fashion. After the first treatment period there was a wash-out period of 1 week followed by the second treatment period of 2 weeks with the other drug.

Drug treatment. Flurbiprofen $1 \times 50 \mathrm{mg}$ tablets q.d.s. or benoxaprofen $1 \times 600 \mathrm{mg}$ tablet at night Paracetamol $1 \mathrm{~g}$ t.d.s. was prescribed regularly throughout the study period; additional doses of $1 \mathrm{~g}$ were given as required.

Clinical assessment. The standard measurements

Table 2 Laboratory data at beginning of study period

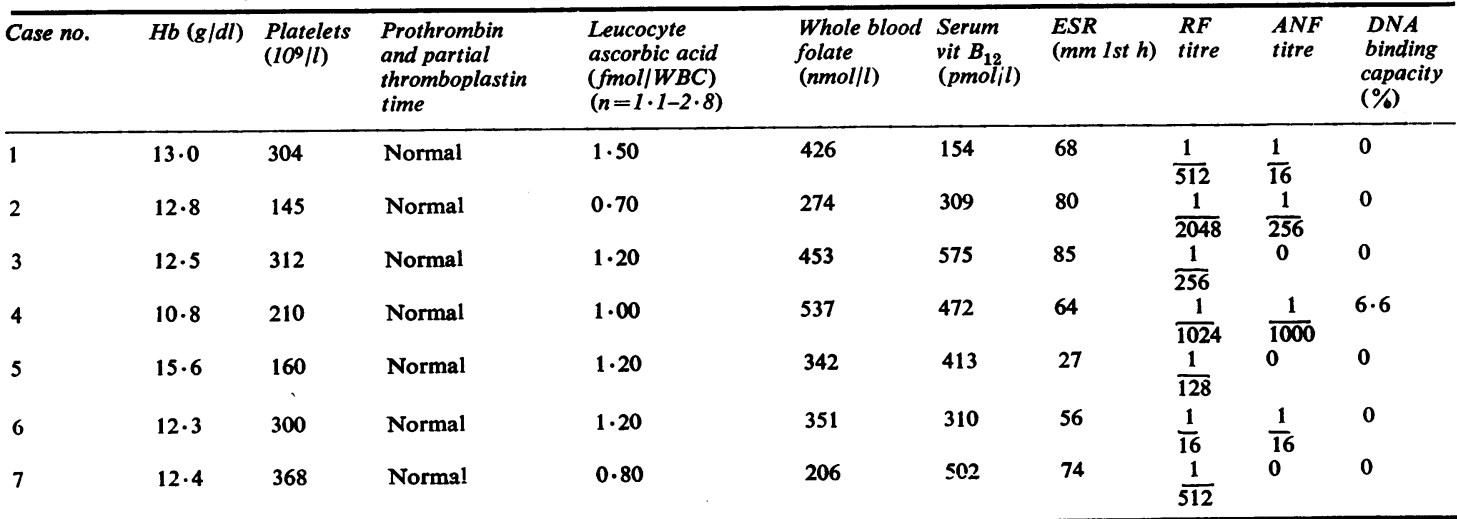

Conversion: SI to traditional units: whole blood folate $1 \mathrm{nmol} / \mathrm{l}=0.441 \mathrm{ng} / \mathrm{ml}$. Serum vitamin $\mathrm{B}_{12} \mathrm{pmol} / \mathrm{l}=1 \cdot 356 \mathrm{pg} / \mathrm{ml}$.

$\mathrm{WBC}=$ white blood cells. ESR $=$ erythrocyte sedimentation rate. $\mathbf{R F}=$ rheumatoid factor. $\mathbf{A N F}=$ antinuclear factor. 
used to assess efficacy of NSAID were performed at weekly intervals. These were: duration of morning stiffness, walking distance over 30 metres, articular index, joint circumference measurements, patient's assessment of pain on a visual analogue scale, patient's own overall assessment, and physician's overall evaluation.

\section{Results}

Variations in the daily rate of blood loss in the 6 patients treated with benoxaprofen and flurbiprofen are shown in Figs. 1 and 2. The data are combined and plotted in Fig. 3. It is clear that in all cases gastrointestinal microbleeding was increased after treatment with flurbiprofen as compared with benoxaprofen. In most cases the maximal effect of flurbiprofen seemed to occur during the second week of treatment. Individual response in terms of the maximal faecal daily blood loss varied considerably over the range of 3-14 ml/day. There is suggestion, especially from the histogram of case 4, that a washout period of 1 week may not always be adequate. In

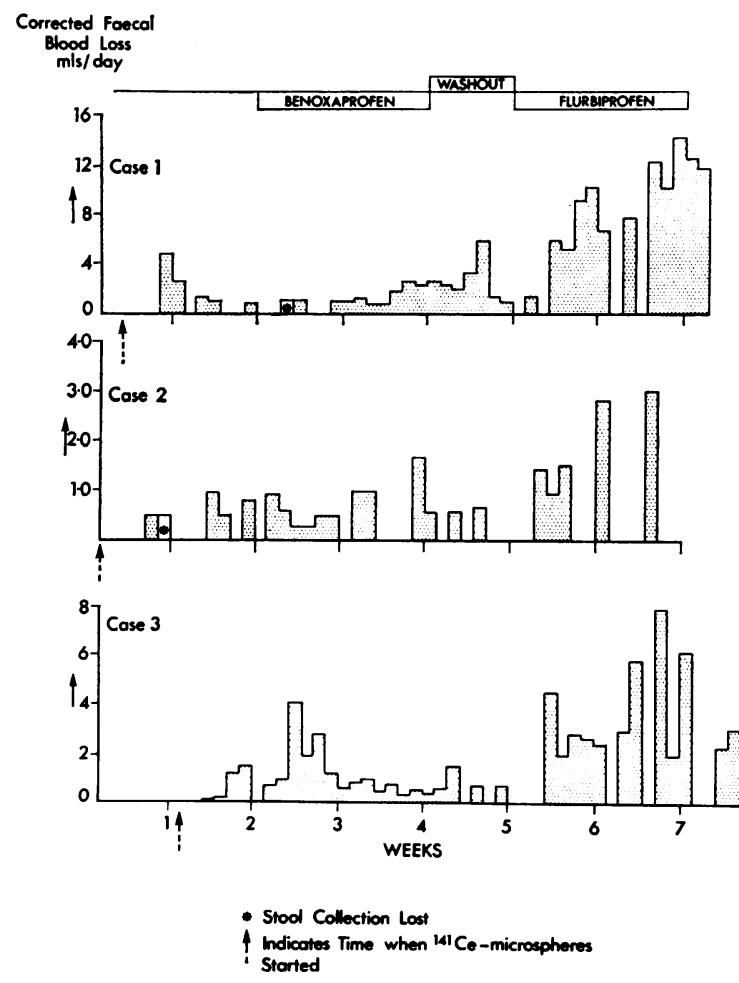

Fig. 1 Corrected daily faecal blood loss for patients given benoxaprofen first.

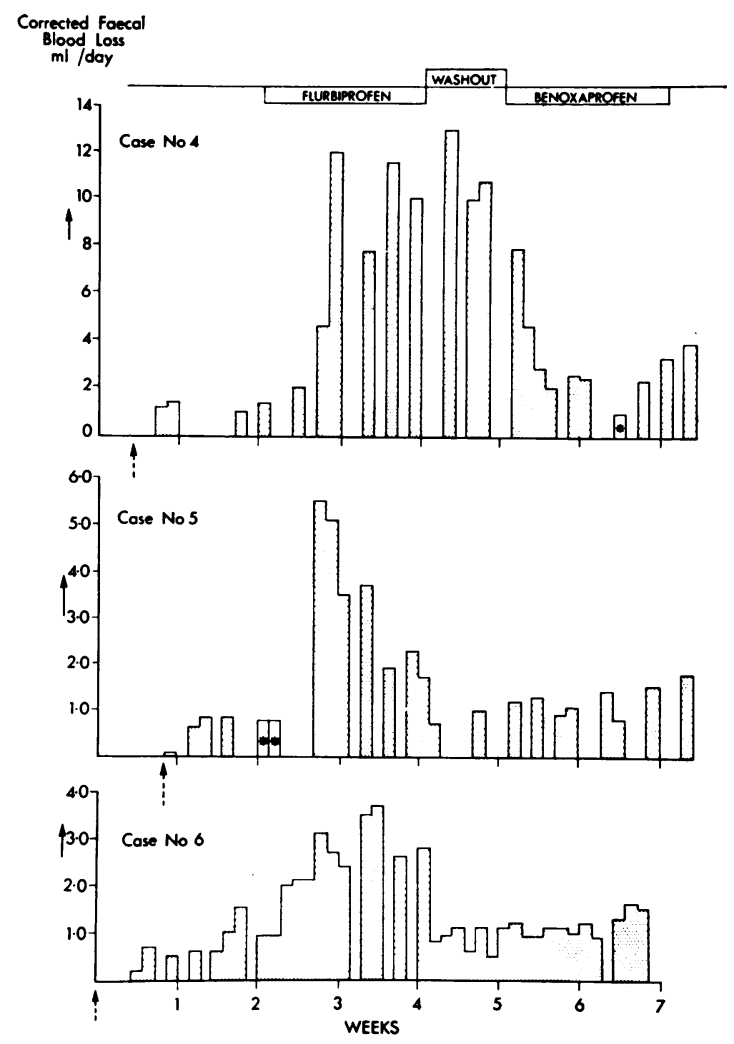

Fig. 2 Corrected daily faecal blood loss for patients given furbiprofen first.

the histogram of case 3 an increase in faecal blood loss occurred during the first week of treatment with benoxaprofen. It is interesting that this happened at a time when the patient had an influenza-like illness with looseness of the stools for a 3-day period.

For statistical analysis the mean daily blood loss over the last 4 days of each week of study was calculated. The results are shown in Table 3, where the patients are grouped according to which of the 2 drugs they were given first. Faecal blood loss was calculated from the last 4 days of each week of study for the following reasons: (i) this would compensate for the time taken for the effect of treatment to be reflected in the counting of the stool specimen; (ii) any tendency for there to be a carry-over effect from previous therapy would be minimised; (iii) this would give some indication of how the effect of the drug increased with time; (iv) the use of this measure would enable this study to be compared with other recently published work on gastrointestinal blood loss in which stool collections were made for limited periods of study. 


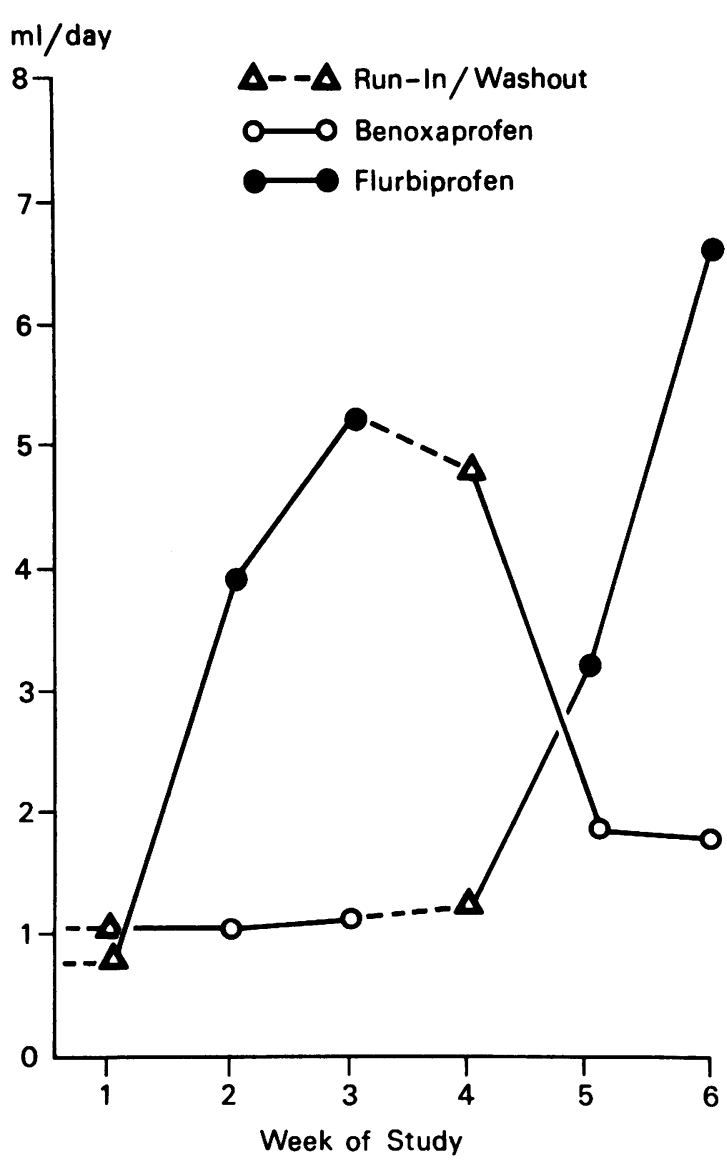

Fig. 3 Combined results for mean daily faecal blood loss for each study week. Each line represents mean results of 3 patients.

Because of the small number of patients in each group nonparametric tests could not be applied to each group separately. The data were therefore combined, but to minimise the carry-over effect of the first drug treatment only results from the second week of each drug treatment period were examined. The small increase in faecal blood loss that followed treatment with benoxaprofen as compared with the run-in period $(0.39$ and $1.07 \mathrm{ml} /$ day in the 2 groups) was not significant overall ( $p>0 \cdot 1$ by the Wilcoxon test for pair differences). With flurbiprofen, however, the observed increase in blood loss $(6.70$ and 4.33 $\mathrm{ml} /$ day in the 2 groups) was found to be significant ( $p<0.05$ by both Wilcoxon and the sign test). When the treatment periods with the 2 NSAID were compared, significantly greater gastrointestinal blood loss $(p<0.05)$ occurred with flurbiprofen. Comparison of the rate of blood loss in the first and
Table 3 Estimates of mean daily faecal blood loss ( $\mathrm{ml}$ ) over last 4 days of each study week

\begin{tabular}{|c|c|c|c|c|c|c|}
\hline \multirow[t]{2}{*}{ Case no. } & \multirow{2}{*}{$\begin{array}{l}\text { Run-in } \\
\text { week }\end{array}$} & \multicolumn{2}{|c|}{ Benoxaprofen } & \multirow{2}{*}{$\begin{array}{l}\text { Washout } \\
\text { week }\end{array}$} & \multicolumn{2}{|c|}{ Fluribiprofen } \\
\hline & & Week 1 & Week 2 & & Week 1 & Week 2 \\
\hline \multirow[t]{3}{*}{$\begin{array}{l}1 \\
2 \\
3 \\
\text { Mean } \\
\text { SD } \\
\end{array}$} & $\begin{array}{l}0.85 \\
0.76 \\
1.14 \\
0.92 \\
0.20\end{array}$ & $\begin{array}{l}1 \cdot 02 \\
0.39 \\
2 \cdot 19 \\
1 \cdot 20 \\
0.91\end{array}$ & $\begin{array}{l}1 \cdot 70 \\
1 \cdot 71 \\
0.53 \\
1 \cdot 31 \\
0.68\end{array}$ & $\begin{array}{l}1.81 \\
0.74 \\
0.68 \\
1.08 \\
0.64\end{array}$ & $\begin{array}{l}7 \cdot 85 \\
1 \cdot 33 \\
2 \cdot 12 \\
3 \cdot 77 \\
3 \cdot 56\end{array}$ & $\begin{array}{r}12 \cdot 56 \\
3 \cdot 07 \\
7 \cdot 24 \\
7 \cdot 62 \\
4 \cdot 76\end{array}$ \\
\hline & & \multicolumn{2}{|c|}{ Flurbiprofen } & & \multicolumn{2}{|c|}{ Benoxaprofen } \\
\hline & & Week 1 & Week 2 & & Week 1 & Week 2 \\
\hline $\begin{array}{l}4 \\
5 \\
6 \\
\text { Mean } \\
\text { SD } \\
\end{array}$ & $\begin{array}{l}0.90 \\
0.80 \\
0.92 \\
0.87 \\
0.06\end{array}$ & $\begin{array}{l}5 \cdot 00 \\
5 \cdot 22 \\
2 \cdot 48 \\
4 \cdot 23 \\
1 \cdot 52\end{array}$ & $\begin{array}{r}10 \cdot 32 \\
2 \cdot 07 \\
3 \cdot 22 \\
5 \cdot 20 \\
4 \cdot 47\end{array}$ & $\begin{array}{r}10 \cdot 80 \\
1 \cdot 04 \\
0 \cdot 78 \\
4 \cdot 21 \\
5 \cdot 71\end{array}$ & $\begin{array}{l}2.41 \\
1.04 \\
1.02 \\
1.49 \\
0.80\end{array}$ & $\begin{array}{l}3 \cdot 15 \\
1 \cdot 24 \\
1 \cdot 42 \\
1 \cdot 94 \\
1 \cdot 05\end{array}$ \\
\hline
\end{tabular}

second weeks of treatment with flurbiprofen gave no significant difference $(p>0 \cdot 1)$, though in 5 cases the rate of blood loss was greater in the second week.

Table 4 gives the amount of ${ }^{141} \mathrm{Ce}$-microspheres retrieved from the same 4-day period stool collections. Clearly with the irregular bowel habits of some patients accurate blood loss estimates would not have been possible without the cerium count.

Fig. 4 illustrates the pattern of blood loss in case 7. At the end of the flurbiprofen treatment period endoscopy was repeated: both gastric and duodenal ulcer sites had remained healed; the whole gastric mucosa appeared hyperaemic, but no erosions were noted. A pentagastrin stimulation test was also performed while the patient remained on cimetidine. Gastric acid secretion was found to be greatly reduced, reaching a maximal acid output of $3.4 \mathrm{eq} / \mathrm{h}$ after overnight fasting.

Testing for faecal occult blood. The Haemoccult test was found to be positive in cases 1 and 4 only when maximal faecal blood loss of more than 10 $\mathrm{ml} /$ day occurred as measured by ${ }^{51} \mathrm{Cr}$ activity. The other stool specimens were all negative by

Table 4 Recovery of ${ }^{141} \mathrm{Ce}(\%$ daily dose) in last 4 days of each week of study

\begin{tabular}{|c|c|c|c|c|c|c|}
\hline \multirow[t]{2}{*}{ Case no. } & \multirow{2}{*}{$\begin{array}{l}\text { Run-in } \\
\text { week }\end{array}$} & \multicolumn{2}{|c|}{ Benoxaprofen } & \multirow{2}{*}{$\begin{array}{l}\text { Washout } \\
\text { week }\end{array}$} & \multicolumn{2}{|c|}{ Flurbiprofen } \\
\hline & & Week 1 & Week 2 & & Week 1 & Week 2 \\
\hline \multirow[t]{3}{*}{$\begin{array}{l}1 \\
2 \\
3\end{array}$} & $\begin{array}{l}317 \\
501 \\
219\end{array}$ & $\begin{array}{l}265 \\
463 \\
287\end{array}$ & $\begin{array}{l}265 \\
234 \\
318\end{array}$ & $\begin{array}{l}419 \\
284 \\
337\end{array}$ & $\begin{array}{l}297 \\
317 \\
458\end{array}$ & $\begin{array}{l}448 \\
268 \\
413\end{array}$ \\
\hline & & \multicolumn{2}{|c|}{ Flurbiprofen } & & \multicolumn{2}{|c|}{ Benoxaprofen } \\
\hline & & Week 1 & Week 2 & & Week 1 & Week 2 \\
\hline $\begin{array}{l}4 \\
5 \\
6\end{array}$ & $\begin{array}{r}409 \\
304 \\
75\end{array}$ & $\begin{array}{l}498 \\
433 \\
178\end{array}$ & $\begin{array}{l}376 \\
186 \\
377\end{array}$ & $\begin{array}{l}237 \\
385 \\
125\end{array}$ & $\begin{array}{l}506 \\
433 \\
251\end{array}$ & $\begin{array}{l}400 \\
331 \\
452\end{array}$ \\
\hline
\end{tabular}




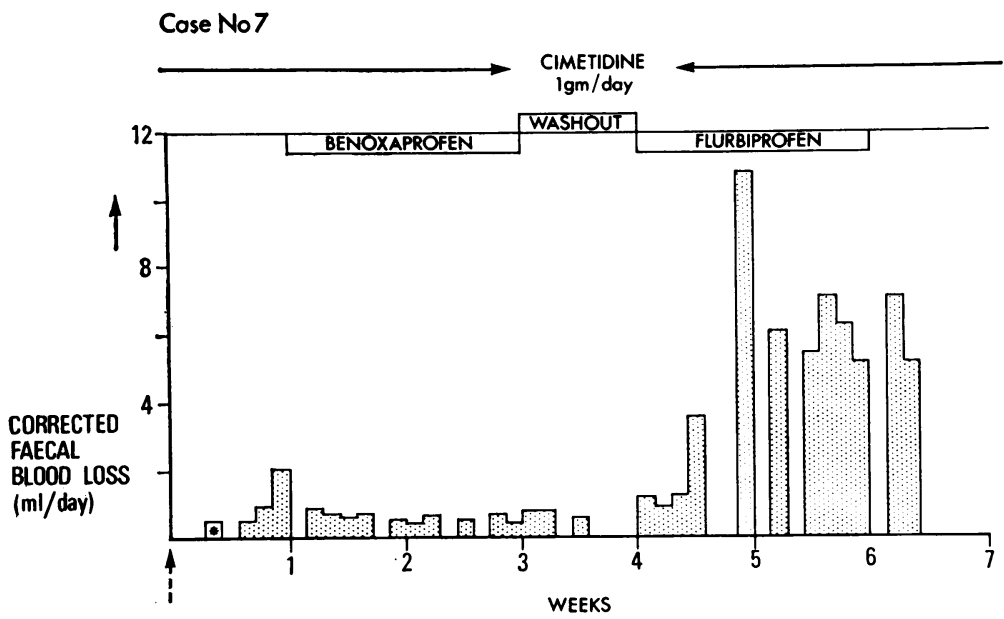

Fig. 4 Corrected daily blood loss in patient receiving cimetidine throughout the study period.
Haemoccult testing as directed by the manufacturers' instructions.

No serious side effects were encountered with either drug used. Case 2 developed a mild photosensitive, itchy rash over the face and arms during the second week of treatment with benoxaprofen. The rash rapidly resolved on stopping the drug. Although the present study was not designed to test the efficacy of the NSAID used, both were found to be equally more effective in giving some symptomatic benefit than paracetamol used alone. There was no significant difference in the number of extra paracetamol tablets given to the patients when they were treated with either flurbiprofen or benoxaprofen.

\section{Discussion}

It has been shown in several animal models that prostaglandins and some of their methyl analogues exert a cytoprotective effect on the gastric mucosa. ${ }^{6} 7$ Protection was conferred not only against damage from oral and parenteral treatment with NSAID that had antiprostaglandin activity, but also from subsequent local application of necrotising agents as varied as boiling water, absolute ethanol, concentrated salt solution, strong $\mathrm{HCl}$, and strong $\mathrm{NaOH}$ solution. ${ }^{13}$ Extrapolation of animal experimental data to man should be made with caution: in rats NSAID can cause severe small intestinal ulceration culminating in fatal peritonitis, ${ }^{14}{ }^{15}$ yet such complication has not been recognised in man despite widespread use of these drugs.

There is a dearth of evidence for the cytoprotective effect of prostaglandins in man, though such evidence is rapidly accumulating. Recently Cohen ${ }^{16}$ and Johannson et al. ${ }^{17}$ reported that giving $\mathrm{PGE}^{2}$ orally along with aspirin and indomethacin respectively prevented the increased faecal blood loss induced by aspirin or indomethacin given alone. The relative antiprostaglandin synthetase activity of benoxaprofen and flurbiprofen is given in Table 5. Our results would give additional indirect support that prostaglandins exert a cytoprotective effect in patients with rheumatoid arthritis in that flurbiprofen, the potent PG synthetase inhibitor, caused increased faecal blood loss consistently, whereas benoxaprofen, the weak inhibitor, did not. Other workers have reported that several NSAID such as indomethacin, aspirin, fenoprofen, and naproxen, which have varying degrees of in-vitro PG synthetase inhibitory activity, also caused increased micro bleeding from the gastrointestinal tract. ${ }^{16-20}$ Benoxaprofen, probably the weakest antiprostaglandin drug of the group, caused no significant increase in faecal blood loss at the present dose used. It is important to note that in recent clinical trials the same dose of benoxaprofen was found to have comparable analgesic and anti-inflammatory effects to the more established drugs such as aspirin, naproxen, indomethacin, and ibuprofen at therapeutic doses. ${ }^{21}$

By measuring faecal blood loss during the whole 6-week study period it became apparent that maximal blood loss with flurbiprofen occurred in

Table 5 Drug concentrations $\left(I_{50} \mu M\right)$ required to inhibit prostaglandin synthetase activity by different in-vitro methods ${ }^{8} 9$

\begin{tabular}{|c|c|c|c|c|}
\hline & $\begin{array}{l}\text { Bovine } \\
\text { seminal } \\
\text { vesicles }\end{array}$ & $\begin{array}{l}\text { Guinea- } \\
\text { pig } \\
\text { lung }\end{array}$ & $\begin{array}{l}\text { Sheep } \\
\text { seminal } \\
\text { vesicles }\end{array}$ & $\begin{array}{l}\text { Human } \\
\text { rheumatoid } \\
\text { synovium }\end{array}$ \\
\hline $\begin{array}{l}\text { Benoxaprofen } \\
\text { Flurbiprofen } \\
\text { Indomethacin }\end{array}$ & $\begin{array}{l}130-210 \\
0 \cdot 02-7 \cdot 0 \\
0 \cdot 07-20\end{array}$ & $\begin{array}{l}300-400 \\
0 \cdot 7 \\
0 \cdot 61-3 \cdot 5\end{array}$ & $\begin{array}{l}150-200 \\
0 \cdot 7 \\
0 \cdot 45-2 \cdot 0\end{array}$ & $\begin{array}{l}0 \cdot 17 \\
0 \cdot 003-2 \cdot 2\end{array}$ \\
\hline
\end{tabular}


most cases during the second week of treatment and that more than 1 week would be required after stopping the drug for the increased bleeding tendency to return to base-line. In some previous studies, in which the NSAID tested was given for only 1 week, the increased blood loss might not have reflected maximal mucosal damage. ${ }^{17} 1920$

The cytoprotective effect of prostaglandins on the gastric mucosa was shown to be mediated independently of the acid-reducing properties possessed by some prostaglandins. ${ }^{22}$ The pattern of blood loss seen in case 7 , in whom increased faecal blood loss occurred despite cimetidine therapy, might indicate that a similar situation occurs in man. This would question the practice of some physicians to prescribe cimetidine regularly 'to cover' the use of NSAID in patients with previous peptic ulcer or prolonged dyspepsia. ${ }^{23}$

\section{CLINICAL SIGNIFICANCE OF INCREASED}

\section{GASTROINTESTINAL MICROBLEEDING}

Chernish et al. ${ }^{20}$ found a good correlation between the measurements of faecal blood loss and endoscopic assessment of gastroduodenal mucosal damage after administration of aspirin and fenoprofen. Measurement of faecal blood loss was, however, a more sensitive indicator of mucosal damage. Most patients who lose about $2-10 \mathrm{ml}$ blood daily can probably compensate for this loss provided they ingest a satisfactory diet, but prolonged loss of more than $10 \mathrm{ml}$ blood/day can cause iron deficiency despite a normal Western diet. Unfortunately many patients with rheumatoid arthritis have a deficient diet because of either a reduced intake or an inability to look after themselves properly. Furthermore, in areas where iron deficiency is common, even the additional loss of less than $5 \mathrm{ml} /$ day may contribute significantly to the anaemia of the rheumatoid patient.

The other important question that remains to be answered is whether a relationship exists between GI microbleeding, the presence of gastric lesions as assessed endoscopically, and acute upper GI haemorrhage. Acute upper GI haemorrhage is relatively rare ${ }^{2425}$ in contrast to microbleeding, which occurred in all our patients treated with flurbiprofen, and to observable gastric lesions, which have been reported in as many as $50 \%$ of patients treated with various NSAID. ${ }^{26} 27$ The possibility remains that other factors such as a subscorbutic state, ${ }^{28}$ alcohol, ${ }^{29}$ or other as yet unidentified factors, as seen in case 3 , may have an additive damaging effect to the mucosa to precipitate a significant haemorrhage. So long as the NSAID in use has anti-PG activity the risk of haemorrhage will probably exist, particularly in those individuals who may have an increased susceptibility to mucosal damage by these drugs. Already the addition of supplementary prostaglandin to NSAID has been proposed as a means of preventing gastric mucosal damage. ${ }^{17}$ Further investigations are needed to determine not only the effects of such a measure on other metabolic pathways but also whether the added prostaglandin would not impair the antiinflammatory effect of these drugs.

The high false negative results obtained with the impregnated guaiac slide test-Haemoccult-highlight the difficulties inherent in the use of this test to detect faecal occult blood. This is important, as this is being widely advocated as a screening method for colonic cancer. ${ }^{30}$ The Haemoccult test was positive in 2 of our patients only when faecal blood loss exceeded $10 \mathrm{ml} /$ day, in keeping with the observation of Stroehlein et al. ${ }^{31}$ that at least $10 \mathrm{ml}$ blood/day was necessary to obtain a positive test in the majority of cases. Winawer ${ }^{32}$ recommended that several precautions should be taken when using this test-for example, the avoidance of ascorbic acid supplements, which may cause a false negative result. Three of the patients in our study were given ascorbic acid supplements without knowledge of this fact at the time.

We acknowledge the helpful advice given by Professor A. Goldberg in the planning of this study and thank Drs A. Glynne and R. Jones, of Eli Lilly Research Centre Limited, for providing us with the benoxaprofen tablets.

\section{References}

1 Roth S H, Boost G. An open trial of naproxen in rheumatoid arthritis with significant esophageal, gastric and duodenal lesions. J Clin Pharmacol 1975; 15: 378-84.

2 Willkens R F. The use of non steroidal anti-inflammatory agents. JAMA 1978; 240: 1632-5.

3 Pitts N E, Proctor R R. Summary: Efficacy and safety of piroxicam. Royal Society of Medicine. International Congress and Symposium Series 1978; 1: 97-108.

4 Vane J R. Inhibition of prostaglandin synthesis as a mechanism of action for aspirin-like drugs. Nature ( $\mathrm{New}$ Biol) 1971 ; 231 : 232-5.

5 Ferreira $\mathbf{S} \mathbf{H}$, Vane $J$ R. New aspects of the mode of action of non-steroid anti-inflammatory drugs. Ann Rev Pharmacol 1974; 14: 57-73.

6 Robert A. Prostaglandins and the digestive system. Prostaglandins 1977; 3: 225-66.

7 Miller T A, Jacobson E D. Gastrointestinal cytoprotection by prostaglandins. Gut $1979 ; 20: 75-87$.

8 Cashin C H, Dawson W, Kitchen E A. The pharmacology of benoxaprofen (2- 4-chlorophenyl - $\alpha$-methyl-5-benzoxazole acetic acid), CRCL 3794, a new compound with anti-inflammatory activity apparently unrelated to inhibition of prostaglandin synthesis. J Pharm Pharmaco 1977; 29: 330-6.

9 Crook D, Collins A J, Rose A J. A comparison of the effect of flurbiprofen on prostaglandin synthetase from human rheumatoid synovium and enzymatically active animal tissues. J Pharm Pharmacol 1976; 28 : 535.

10 Ropes M W, Bennett G A, Cobb S, Jacox R, Jessar R A. 
1958 Revision of diagnostic criterion for rheumatoid arthritis. Arthritis Rheum 1959; 2: 16-20.

11 The International Committee for Standardization in Hematology. Recommended methods for radioisotope red cell survival studies. Blood $1971 ; 88$ : 378-86.

12 Carmichael R H, Crabtree R E, Ridolfo A S, Fasola A F, Wolen $\mathbf{R}$ L. Tracer microspheres as a fecal marker in balance studies. Clin Pharmacol Ther 1973; 14: 487-91.

13 Robert A, Nezamis J E, Lancaster C, Hanchar A J. Cytoprotection by prostaglandins in rats. Prevention of gastric necrosis produced by alcohol, $\mathrm{HCl}, \mathrm{NaOH}$, hypertonic $\mathrm{NaCl}$ and thermal injury. Gastroenterology $1979 ; 77: 433-43$.

14 Kent T H, Cardelli R M, Stamler F W. Small intestinal ulcers and intestinal flora in rats given indomethacin. Am J Pathol 1969; 54: 237-49.

15 Wax J, Clinger W A, Varner P, Bass P, Winder C V. Relationship of the enterohepatic cycle to ulcerogenesis in the rat small bowel with flufenamic acid. Gastroentero$\log y 1970 ; 58$ : 772-80.

16 Cohen M M. Mucosal cytoprotection by prostaglandin $\mathrm{E}_{2}$. Lancet $1978 ; 2$ : $1253-4$.

17 Johansson C, Kollberg B, Nordemar R, Samuelson K, Bergström S. Protective effect of prostaglandin $E_{2}$ in the gastrointestinal tract during indomethacin treatment of rheumatic diseases. Gastroenterology 1980; 78: 479-83.

18 Scott J T, Porter I H, Lewis S M, Dixon A St J. Studies of gastrointestinal bleeding caused by corticosteroids, salicylates and other analgesics. $Q J$ Med $1961 ; 30: 167-88$.

19 Loebl D H, Craig R M, Culic D D, Ridolfo A S, Falk J, Schmid F R. Gastrointestinal blood loss. JAMA 1977; 10: $976-81$.

20 Chernish S M, Rosenak B D, Brunelle R L, Crabtree R.
Comparison of gastrointestinal effects of aspirin and fenoprofen. Arthritis Rheum 1979; 22 : 376-83.

21 Proceedings of the international symposium on benoxaprofen, Weisbaden, West Germany Sept 1-2, 1979. $J$ Rheumatol 1980; 7: suppl 6.

22 Robert A. Antisecretory, antiulcer, cytoprotective and diarrheogenic properties of prostaglandins. Adv Prostaglandin Thromboxane Res 1976; 2: 507-20.

23 Crocker J R, Cotton P B, Boyle A C, Kinsella P. Cimetidine for peptic ulcer in patients with arthritis. Ann Rheum Dis $1980 ; 39$ : 275-8.

24 Jick H, Porter J. Drug-induced gastrointestinal bleeding. Lancet 1978 ; ii: 87-9.

${ }^{25}$ Levy M. Aspirin use in patients with major upper gastrointestinal bleeding and peptic-ulcer disease. $N$ Engl J Med 1974; 290: 1158-62.

26 Caruso I, Bianchi Porro G. Gastroscopic evaluation of anti-inflammatory agents. $\mathrm{Br}$ Med J 1980; i: 75-8.

27 Silvoso G R, Ivey K J, Butt J H, et al. Incidence of gastric lesions in patients with rheumatic disease on chronic aspirin therapy. Ann Intern Med 1979; 91 : 517-9.

${ }^{28}$ Russell R I, Goldberg A. Effect of aspirin on the gastric mucosa of guinea pigs on a scorbutogenic diet. Lancet 1968 ; ii: $606-8$.

29 Goulston K, Cooke A. Alcohol, aspirin, and gastrointestinal bleeding. $\mathrm{Br}$ Med J 1968; iv: 664-5.

30 Greegor D H. Occult blood testing for detection of asymptomatic colon cancer. Cancer $1971 ; 28$ : 131-9.

31 Stroehlein J R, Fairbanks V F, McGill B B, Go V L. Hemoccult detection of fecal occult blood quantitated by radioassay. Am J Dig Dis 1976; 21 : 841-4.

32 Winawer S J. Editorial: Fecal occult blood testing. Am J Dig Dis 1976; 21 : 885-8. 